Historic, Archive Document

Do not assume content reflects current scientific knowledge, policies, or practices. 



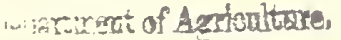

\section{BETTER \\ PLANTS \\ PLANTS \\ God's first gift to man was a Beautiful Garden}

VoL. VII JULY-AUGUST, 1929

Number 4

\section{All Kinds of Irises at All Kinds of Prices}

\section{As Low as 5 Cents Each-Roots for Less than the Cost of Cut-Flowers}

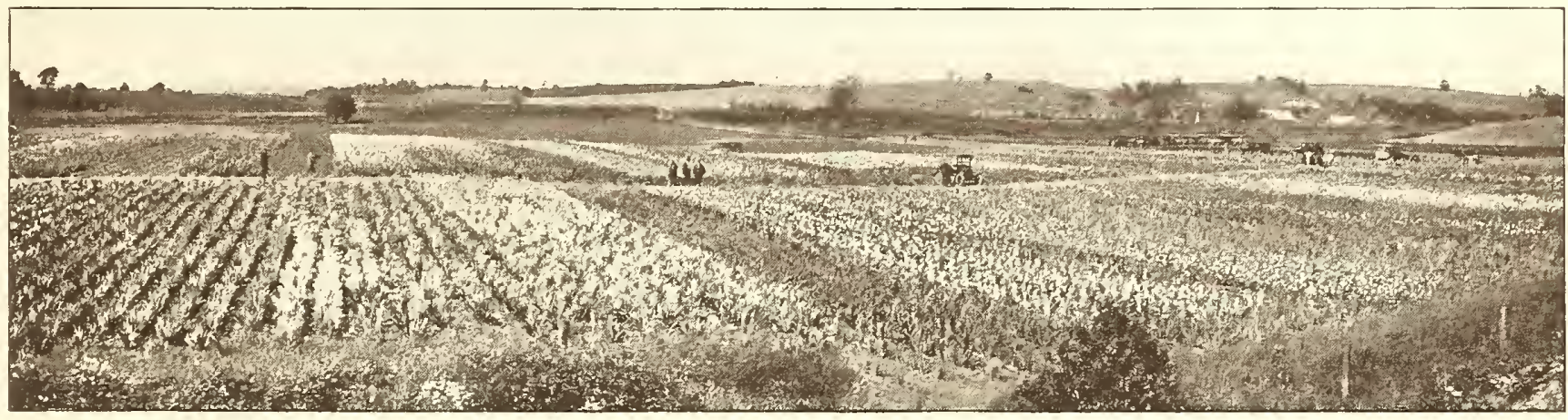

Looking across the field of Iris at Weiser Park, June, 1929. It is from these blocks that your orders will be filled this fall. How many plants do you suppose are in this immense field?

\section{CASH OR THE PLOW-TAKE THEM NOW!}

We have too many roots of many good varieties of Irisesa condition which is our misfortune but your opportunity. The surplus must be sold or plowed under this year, and prices have therefore been set accordingly. Such low cost permits planting Irises in every nook and cranny of the garden-along hedges, curbs, borders-EVERYWHERE. This will be our last offer on these varieties; next will be shipment or the plow. There should be an adequate supply for all prompt orders.

\section{A Gift for Friends or Institutions}

These prices will encourage Iris gifts to friends and institutions. We shall be glad to ship to any address furnished and to bill to the purchaser.

Plants Shipped on Approval

Although these prices are the lowest ever offered, you can expect the same quality as though you were paying $\$ 1$ per root. If you do not agree that the quality is of the finest, you may return the roots at our expense.

Terms Thirty Days

Send no money with the order. Wait until you have seen the roots and judged them. If they please you, pay within 30 days. If they do not please you, send them back at our expense. You can appreciate that we have confidence in the quality or we would not make this offer.

\section{Trueness Guarantee}

Every root is guaranteed to be true to name. Reports of untrueness will be accepted in Iater years, without argument, although we do not expect such reports to be necessary. Replacement will be made in double quantity.

\section{Buy These Irises by the Hundred or More}

At the prices here given you can fill your garden with a mass of self-increasing and self-sustaining color and beauty. Use Irises where other plants will not succeed. Irises will conquer drought and weeds, and their abundant and colorful blooms will make them future companions for the most delicate plants.

50 or more of one kind at 5 cents each-Seventeen varieties in the group

\section{Aurea Maculata. Dwarf. Flecked yellow. Gerda. Early. Large; yellow.}

Blue Beard. Dwarf. White and blue.

Col. Candelot. Smoky crimson.

Drake. Clear light blue.

Florentina. Early. White.

Fro. Yellow and brown.
Germanica. Old-fashioned Blue Flag.

Giran. Showy crimson-purple.

Helge. Yellow and purple.

Ingeborg. Early. Large; white.

Loreley. Yellow and blue.
Mary Orth. Large; blue and violet.

Miranda. Clear violet-blue, orange beard.

Myth. Large; clear blue.

Navajo. Yellow and maroon.

Nine Wells. Late. Violet and purple.

N. B.-Less than 50 of one kind at following prices: 10 or more of one kind at 10 cts. each; 25 or more of one kind at 8 cts. each. Not less than 10 plants of one variety sold.

Our revised and enlarged list of French Hybrid Lilacs will reach you during early September. 


\section{IRISES FOR MASS COLOR DISPLAY}

Use Irises for borders, along walks, drives, fences, around garden pools, beside steps and in foundation groups.

Use Irises for bedding, for planting at the base of terraces, on slopes and banks, and in general mass displays.

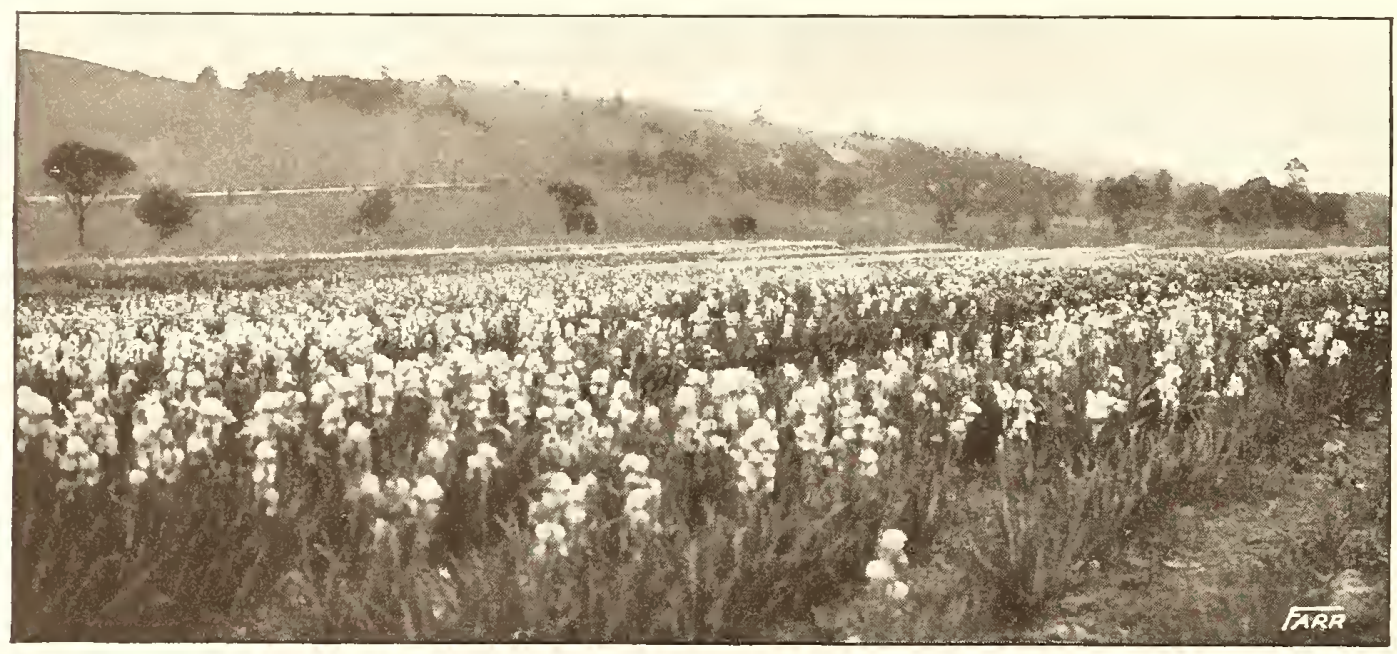

Here is another planting of Farr Irises at Weiser Park; Wm. Penn Highway in background. Wouldn't you like to have some of these plants in your garden next year? This issue of Better Plants gives you the opportunity.

50 or more of one kind at 8 cents each

Flavescens. Soft yellow; tall.

Foster's Yellow. Creamy yellow.

Mrs. H. Darwin. Favorite white.

Rhein Nixe. White, with blue, edged white.

Sherwin-Wright. Golden yellow.

Walhalla. Lavender and blue.

N. B.-Less than 50 of one kind at following prices: 10 or more of one kind at $12 \mathrm{cts}$. each; 25 or more of one kind at $10 \mathrm{cts}$. each.

\section{Siberian and Water Irises}

Siberian Purple. Unnamed Siberian Emperor. Purple

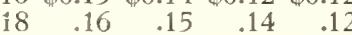
$\begin{array}{llllll}\text { Pseudacorus. Yellow Water Iris } & .18 & .16 & .15 & .14 & .12\end{array}$ Versicolor. Blue Water Iris

\begin{tabular}{|c|c|c|c|c|}
\hline \multicolumn{5}{|c|}{ EACH, PRICE PER RO } \\
\hline Roots & & Roots & $\begin{array}{l}50 \\
\text { Roots }\end{array}$ & $\begin{array}{c}100 \\
\text { Roots }\end{array}$ \\
\hline$\$ 0.16$ & $\$ 0.15$ & $\$ 0.14$ & $\$ 0.12$ & $\$ 0.12$ \\
\hline 18 & .16 & .15 & .14 & .12 \\
\hline .18 & $\therefore 6$ & .15 & 14 & .12 \\
\hline .16 & 15 & .14 & .12 & \\
\hline
\end{tabular}

\section{Farr's Collections of Unnamed Iris}

30 plants in 5 varieties, our selcction 30 plants in 10 varieties, our selection 50 plants in 5 varieties, our selection 50 plants in 10 varieties, our selection

\section{0 plants in 5 varieties,}

\section{0 or more of one kind at $\mathbf{1 0}$ cents each} Albert Victor. Blue and lavender. Alcazar. Violet and purple. Aurora. Pale pink.

Dalila. White and plum.

Dawn. Light yellow.

Etta. Early; eream-yellow.

Fairy. White, suffused blue.

Her Majesty. Pink.

Iris King. Yellow and maroon. Juniata. Late; tall; elear blue.

Ma Mie. White with blue edges.

Pocahontas. White, edged blue.

Princess Victoria Louise. Yellow and plum.

Queen of May. Pink.

N. B.-Less than 50 of one kind at following prices: 10 or more of one kind at $15 \mathrm{cts}$. each; 25 or more of one kind at 14 cts. each.

\section{CHRYSANTHEMUM}

\section{ARCTICUM (Arctic Daisy)}

Onc of the few dwarf fall bloomers and by far the best and latest. Flowers white, shading to pink, borne in profusion in Oetober and November. Foliage forms clean and attractive rosettes all summer. Grows 12 to 15 inehes high. Fine for borders, edging or rockeries. 3 for $\$ 1 ; 5$ or more at $25 \mathrm{c}$. each; 25 or more at $20 \mathrm{c}$. each.

\section{How to Prepare for Planting Irises}

Little preparation is neccssary for the planting of Iriscs. Add lime to the soil if it is acid and you intend to plant bulbous varieties. Plant bulbous Irises so that the upper third or fourth of the bulb is exposed to sun and air. Plant fibrous sorts even to the crown, and where the soil is not of heavy lime eontent.

\section{Lecture Service}

Mr. H. G. Seyler, the editor of Better Plants and Treasurer of Farr Nursery Company, is available for a limited number of Iectures on Irises or Peonies. The lectures are illustrated by colored lantern slides. Terms are travel cxpenses and a $\$ 10$ lecture fee. Mr. Seyler cannot leave the nursery during bloom seasons (April, May, and early June). Write if this service is desired at any other time. 
Postage

will be paid

by

Addressee
No

Postage Stamp

Necessary If

Mailed Before

April 1st, 1930

BUSINESS REPLY ENVELOPE

First Class Permit No. 1, Sec. 39413/3 P. L. \& R. Weiser Park, Pa.

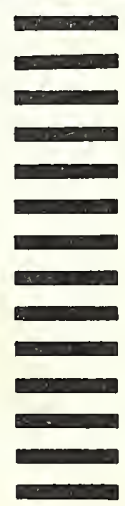

FARR NURSERY COMPANY

WEISER PARK,

PA. 
Send no monisy

\section{IRIS SPECIAL \\ AN OPPORTUNITY TO TRANSFORM \\ YOUR GARDEN IITO R:OTOUS COLOR AT LOW COST}

until you have

seen the plants.

Terrns so diny:

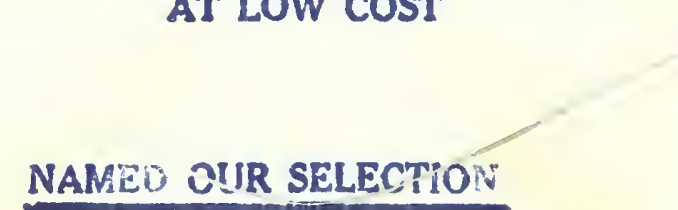

Plants will

have name labels attached. Return if not satisfied

$\begin{array}{llrrr}30 & \text { plants in } 5 & \text { varieties } & \$ 3.70 \\ 30 & \text { " } & 10 & " & 3.75 \\ 50 \text { " } & \text { " } & 5 & " & 4.50 \\ 50 & \text { " } & & " & 5.50 \\ 100 " & \text { " } & 5 & " & 7.75 \\ 100 " & \text { " } 10 & " & 9.75 \\ 100 " & \text { " } 20 & \text { " } & 12.25\end{array}$

We chiaposed of more than 400 inferior in varietiog recentiy. Above collections will be seltced from the remaining bettet sorts. 


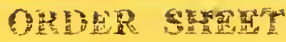 \\ BERTRAND II. FARR \\ Homissing Narseries Compary \\ WEISER PARK, WOMELSDOEF, PEINA.}

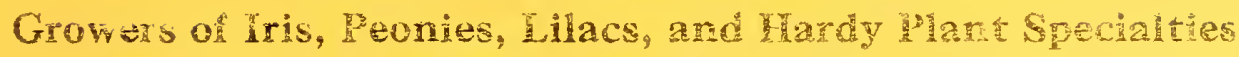

Ship to (Name)

Daie

Street or R. If. I. No.

Traven ar Cily.

Combly-

Stitie

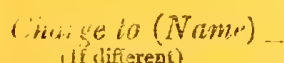

drivess

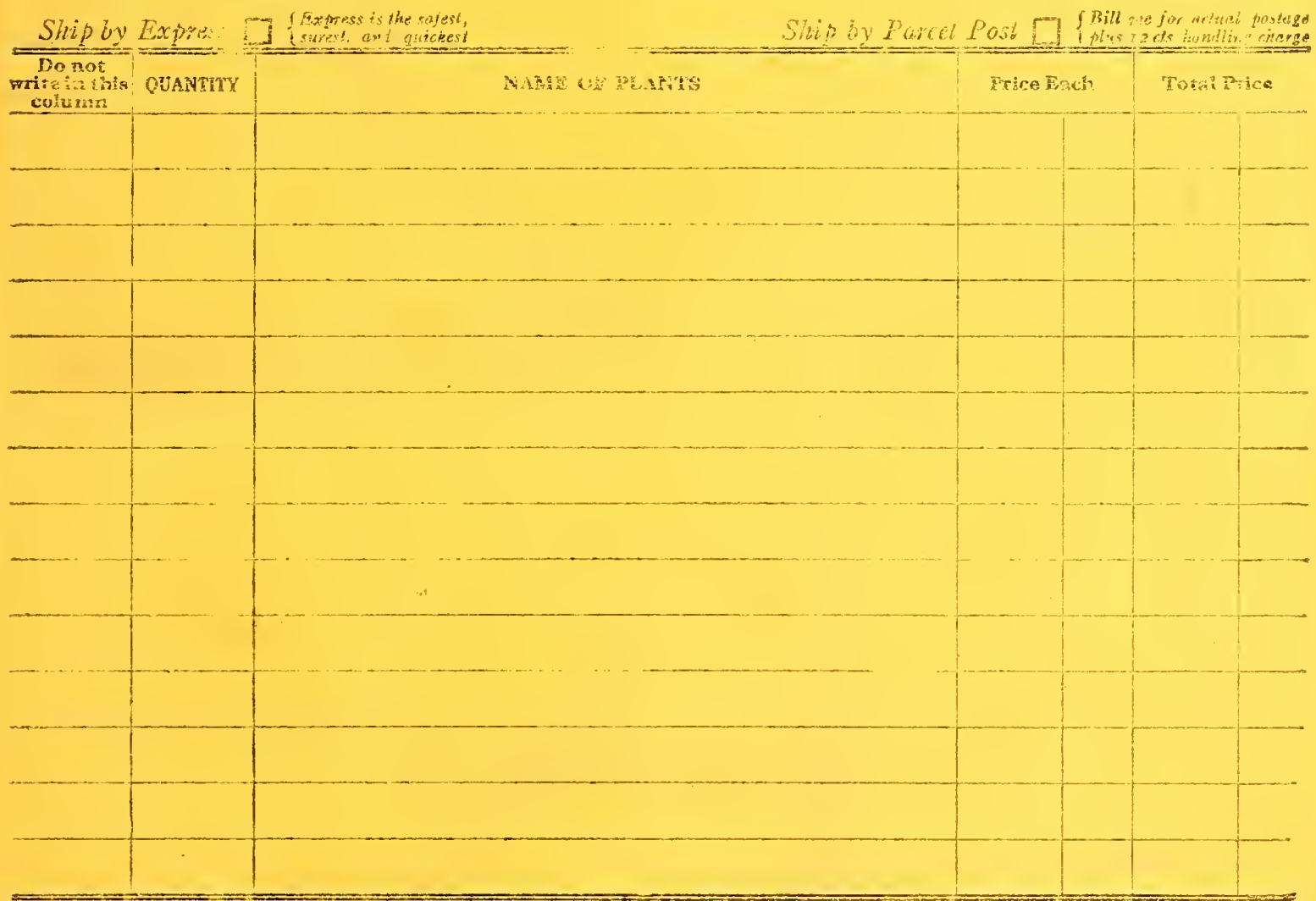

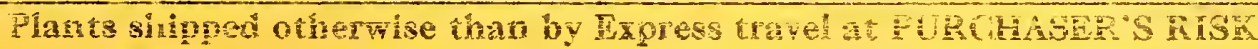

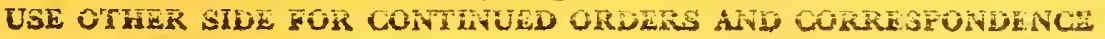




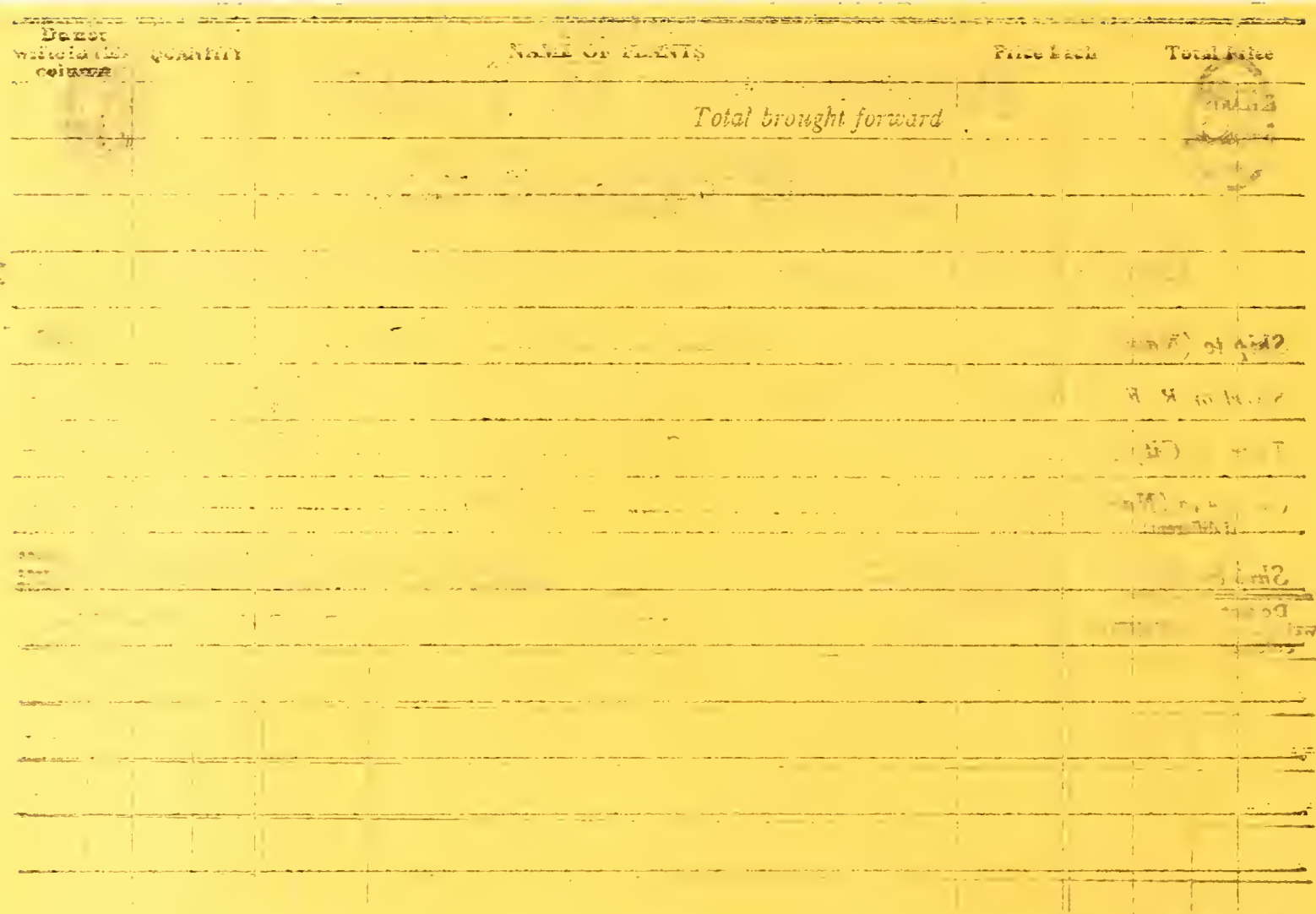

$=$

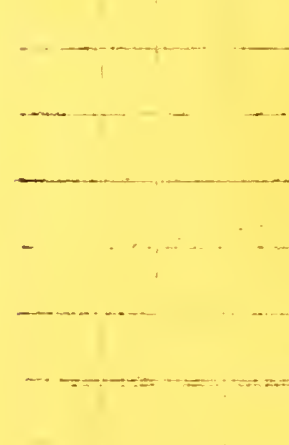

\section{PTASE SWH A COPY OH YOUR CATALCGU WIV WIY CONRDISENTS TO}

Tatie

Aderss 


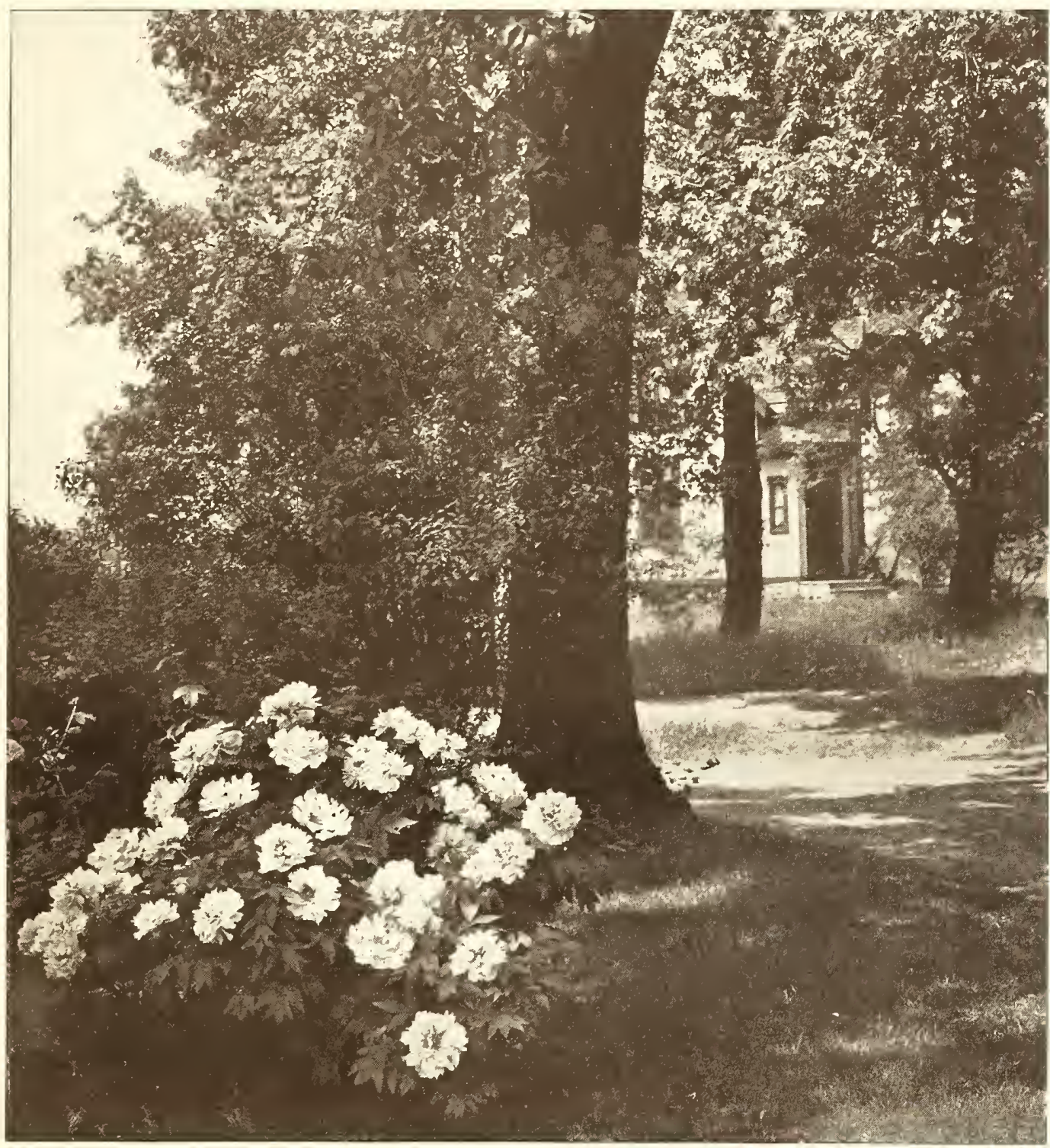

\section{TREE PEONIES-For Autumn, 1929}

Lately the "Flower of the Emperor," Tree Peonies are now becoming available for American gardens. The plants develop into large bushes, bearing hundreds of blooms borne on hardwood branches; comparable to the lilac in hardiness, and excelling Herbaceous Peonies in size, texture and color range.

Culture. - Once established, Tree Peonies are as hardy as lilacs. For the first winter they should be mulched heavily with clean materials. South and east exposures are the best locations and none except mature, established plants should be exposed to the north and west winter winds. Feed with Vigoro. Keep watered and cultivated. Plant deeply. Double varieties frequently bloom single and semi-double until thoroughly established. Tips of branches die back during winter, but plants gradually grow into bushes 3 to 6 feet in height and spread, bearing, in many cases, more than a hundred blooms. Tree Peonies bloom from two to three weeks earlier than herbaceous varieties and blooms are larger and more beautiful. Petals in most cases resemble crêpe paper. Colors are clear and intense. Planting and shipping during autumn or spring: August to November, March to May 1.

La Lorraine. Yellow; double. 10 to 12 in. $\$ 100$.

Souv. M. Cornu. Yellow, edged purple; double. 10 to $12 \mathrm{in}$. $\$ 100$.

Moutan. Single; red; vigorous; prolific. 12 to 18 in. $\$ 6$.

Banksi. Double; pink; vigorous; prolific. 12 to 18 in. $\$ 6$.

Assorted Unnamed, 2-year-old, blooming size plants, without descriptions or warranty as to color except that all Tree Peonies are beautiful. $\$ 3.50$ each.

Royal Collection of Tree Peonies. Five 2-year-old, unnamed plants in assortment for $\$ \mathbf{1 6}$ complete. Collection guaranteed to include at least three diffcrent kinds; returnable for replacement, if otherwise after they bloom. 


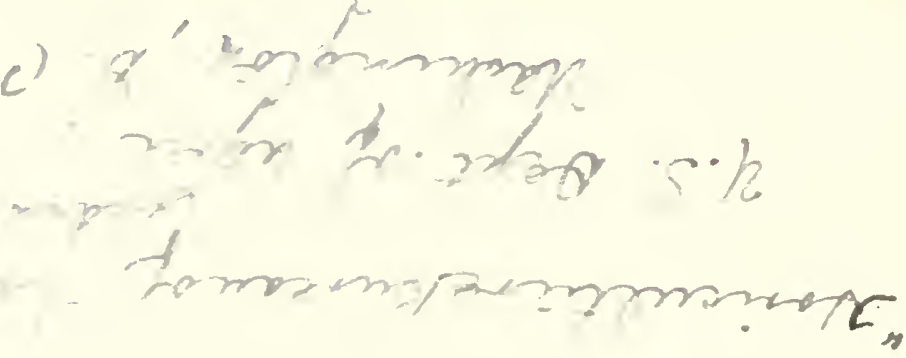

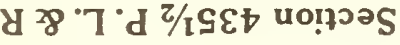

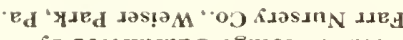

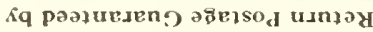

- sseis uMet

suniurydja

se!.อิว!nbV

..... xolyd

səiddod

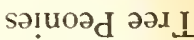

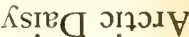

słuวs $\subseteq$ fe sIII

Jəquin N Jәயüsp!W S!Ył Jo

s7uว7uOD วนL

\section{MIXED PEONIES}

Our mixed Peonies are the result of discarding more than 400 varieties some years ago. They are of unusual interest, variety, and value, and are not to be confused with ordinary Peonies. Should be bought in quantity so as to obtain wide and interesting assortment. 5 or more at 35 cts. each; 25 or more at $30 \mathrm{cts}$. each; 50 or more at 25 cts. each.

\section{FERN-LEAF PEONY (Pronia tenuifolia)}

This is the very earliest of all Peonies to bloom, and is of both botanical and ornamental interest. It is usually scarce and slow to increase. Blooming size plants at $\$ 2.50$ each.

\section{OLD-FASHIONED EARLY PEONY}

(Paonia officinalis rubra)

For some years we have been quietly working to accumulate a good stock of this old favorite variety. This is the Peony which can always be depended upon to bloom around Memorial Day. It is a money-maker, as it frequently is sold at $25 \mathrm{cts}$. per bloom, and a plant can pay for itself within a year or two. $\$ 1.50$ each: 5 or more at $\$ 1$ each; 25 or more at 80 cts. each.

\section{AQUILEGIA (Columbine)} Weiser Park Hybrids

These are grown from selected types and colors of the Iong-spurred Mrs. Scott Elliott's strain. They grow 18 to 30 inches high and bloom profusely in June and July. One of the best ten perennials. Fine for natural and rock planting. Mixed colors. 3 for $\$ 1 ; 5$ or more at 25 cts. $; 25$ or more at 22 cts.

\section{HARDY PHLOX}

B. Comte. Rich satiny am- Each 10 aranth.........\$0.35 $\$ 3.00$

Europe. White, crimson eye. .353 .00 Elizabeth Campbell. Light salmon, changing to pink.... $.40 \quad 3.50$

Frau Anton Buchner. White ..................... white, Iarge rose center..... Le Mahdi. Metallic bluish violet. . . . . . . . . . . .

Miss Lingard. White, faint lilac eye.................. deeper tone..............

Rheinlander. Pink ............

Richard Strauss. Very dark violet-amaranth . . . . . . .

R. P. Struthers. Brig
son and rosy red, eye. . .

William Ramsey. vety purple, very bri $i_{F}$

Widar. Viol white eye.

$.35 \quad 3.00$

.353 .00

.353 .00

$.35 \quad 3.00$

$.35 \quad 3.00$

.353 .00

$.35 \quad 3.00$

Fraulein von Lassburg. White

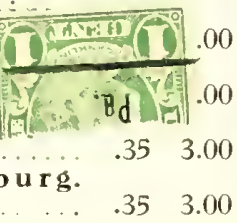

\section{DELPHINIUM (Larkspur) Weiser Park Hybrids}

This is our own improved strain, produced from selected English seedlings and Farr Gold Medal Hybrids, and including a heavy proportion of types which, if segregated and named, would be worth fancy prices. They produce very large flowers and spikes from May to September and reach a height of 40 to 60 inches. Fine for border background. Mixed, blue and pink, single and double. $50 \mathrm{cts}$. each; 5 or more at $40 \mathrm{cts}$. each; 25 or more at 35 cts. each.

\section{FARR NURSERY COMPANY Weiser Park, Pennsylvania}

\section{ORIENTAL POPPIES}

Edna Perry. For the last ten years we have been endeavoring to produce a suff:cient quantity of this choice variety to meet the demand. The blooms are unusually Iarge, of soft salmon-pink color, and produced with more than ordinary freedom. The plants seem to be unusually hardy and vigorous. This year we offer 2-year-old field-grown clumps, with six to ten blooming stems, at $\$ 1$ each; 5 or more clumps at 70 cts. each; 25 or more clumps at 60 cts. each.

Strong divisions from these clumps, which should bear from two to five blooms next ycar, are offered at $\mathbf{5 0}$ cts. each: 5 or more at 30 cts. each: 25 or more at 25 cts. each.

Royal Scarlet. The rich glowing scarlet flowers are of medium size and produced in greatest profusion. A strong grower. Clumps $\$ 1$ each; 5 or more clumps at 70 cts. each; 25 or more clumps at $60 \mathrm{cts}$. each.

Strong divisions at $\mathbf{5 0}$ cts. each; 5 or more at $30 \mathrm{cts}$. each; 25 or more at $25 \mathrm{cts}$. each.

\section{WEISER PARK}

\section{EVERGREEN LAWN SEED}

A mixture of the best native and imported grasses: Redtop, Blue Grass, Rye Grass, Fescues, Timothy, White Clover. A superior Lawn Seed for homes, golf courscs, cemeteries, parks, etc. Makes a fine, smooth, velvety lawn, with plants growing evenly. Seed germinates well and is 98.90 per cent pure of weeds. Given proper care, your new lawn will greatly improve the appearance of your grounds in a very short time after seeding with Weiser Park Evergreen Lawn Seed.

5 lbs. at 35 cts. per 1 b.; 25 lbs. at 30 cts. per lb. ; 50 lbs. at 28 cts. per lb. $100 \mathrm{lbs}$. at 27 cts. per lb., f. o. b. Weiser Park. 